\title{
Changes of Cytokine and Chemokine mRNA Expression in Whole Blood Cells from Active Pulmonary Tuberculosis Patients after T-Cell Mitogen and Mycobacterium tuberculosis Specific Antigen Stimulation
}

\author{
Sunghyun Kim ${ }^{1,2,}$, Sangjung Park ${ }^{3, \$}$, and Hyeyoung Lee ${ }^{1, \uparrow}$ \\ ${ }^{I}$ Department of Biomedical Laboratory Science, College of Health Sciences, Yonsei University, Wonju 220-710, Korea \\ ${ }_{2}^{2}$ Institute for Life Science and Biotechnology, Yonsei University, Seoul 120-749, Korea \\ ${ }^{3}$ Department of Clinical Laboratory Science, College of Medical Science, Daegu Haany University, \\ Gyeongsan 712-715, Korea
}

\begin{abstract}
Tuberculosis (TB) is one of the major global health problems and it has been estimated that in $5 \sim 10 \%$ of Mycobacterium tuberculosis (MTB)-infected individuals, the infection progresses to an active disease. Numerous cytokines and chemokines regulate immunological responses at cellular level including stimulation and recruitment of wide range of cells in immunity and inflammation. In the present study, the mRNA expression levels of eight host immune markers containing of IFN- $\gamma$, TNF- $\alpha$, IL-2R, IL-4, IL-10, CXCL9, CXCL10, and CXCL11 in whole blood cells from active pulmonary TB patients were measured after T-cell mitogen (PHA) and MTB specific antigens (ESAT-6, CFP-10, and TB7.7). Among the TH1-type factors, IFN- $\gamma$ mRNA expression was peaked at $4 \mathrm{~h}, \mathrm{TNF}-\alpha$ and IL-2R mRNA expression was significantly high at the late time points (24 h) in active TB patients, TH2-type cytokine (IL4 and IL10) mRNA expression levels in both active TB and healthy controls samples did not changed significantly, and the mRNA expression of the three IFN- $\gamma$-induced chemokines (CXCL9, CXCL10, and CXCL11) were peaked at the late time points (24 h) in active TB patients after MTB specific antigen stimulation. In conclusion, the mRNA expression patterns of the TB-related immune markers in response to the T-cell mitogen (PHA) differed from those in response to MTB specific antigens and these findings may helpful for understanding the relationship between MTB infection and host immune markers in a transcripts level.
\end{abstract}

Key Words: Active pulmonary tuberculosis, Cytokines, Chemokines, T-cell mitogen, Mycobacterium tuberculosis specific antigens

Tuberculosis (TB) is mainly caused by Mycobacterium tuberculosis (MTB) and it remains a major infectious disease with approximately 9.3 million new TB cases annually and 1.8 million deaths per year. Forty thousand new cases of TB and 3,000 deaths occur in the Republic of Korea every

\footnotetext{
*Received: June 25, 2014 / Revised: September 12, 2014

Accepted: September 17, 2014

${ }^{\S}$ Equal contributors

${ }^{\dagger}$ Corresponding author: Hyeyoung Lee. Department of Biomedical Laboratory Science, College of Health Sciences, Yonsei University, 1 Yonseidae-gil, Wonju 220-710, Korea.

Tel: +82-33-760-2740, Fax: +82-33-760-2561

e-mail: hyelee@yonsei.ac.kr

(T) The Korean Society for Biomedical Laboratory Sciences. All rights reserved.
}

year (Dye, 1999; Lew, 1995). Most MTB infections are asymptomatic however about $10 \%$ of all infections eventually progress to active TB disease (Comstock, 1974). Typically, about $90 \%$ of active cases are pulmonary TB disease and $15 \sim 20 \%$ of active cases are extrapulmonary TB disease including tuberculous pleurisy, meningitis, lymphadenitis, and urogenital TB (Golden, 2005). The 6 $\mathrm{kDa}$ early secretory antigenic target (ESAT-6) and $10 \mathrm{kDa}$ culture filtrate antigen (CFP-10) of MTB form a heterodimeric complex and both genes are expressed from region of difference 1 (RD1) region (Renshaw, 2005). These secretory antigens (proteins) contribute to the virulence of 
MTB and have a potential of T-cell antigen (Pathak, 2007; Meher, 2006). TB7.7 is encoded by a phage-inserted region (phiRv2) which is highly specific for MTB (Behr, 1999; Brosch, 2002; Cole, 1998). Phytohaemagglutinin (PHA) is a lectin found in plants and which is very useful as a mitogen to trigger T-cell division and activation (Hamelryck, 1996). Cytokines and chemokines regulate immunological responses at cellular level including stimulation and recruitment of wide range of cells in immunity and inflammation. Cytokines have pleiotropic actions, cascade effect, and antagonistic action and chemokines have homeostatic action, roles in promoting angiogenesis or guide cells to tissues, and inflammatory effect (Adane and Markos, 2013). Numerous cytokines and regulatory factors have been implicated in the pathogenesis of TB (Ulrichs, 1998; Dlugovitzky, 1999; Azzurri, 2005; Okamoto, 2005). Other studies have shown that IFN- $\gamma$, TNF- $\alpha$, and IL-2 expression profiles of CD4+ T-cells were highly observed in active TB disease (Harari, 2011) and IL-4 and IL-10 levels were also closely linked to active TB (Walzl, 2011). CXCL9 (monokine induced by interferon gamma, MIG), CXCL10 (interferon gamma inducible protein 10, IP-10), and CXCL11 (interferoninducible T cell alpha chemoattractant, I-TAC) are inflammatory chemokines which is induced by pro-inflammatory cytokines and secreted by monocytes or macrophages. These chemokines have been found in a various TB diseases (Kaplan, 1987; Okamoto, 2005; Juffermans, 1999). In the present study, relative mRNA expressions of IFN- $\gamma, \mathrm{TNF}-\alpha$, IL-2R, IL-4, IL-10, CXCL9, CXCL10, and CXCL11 in whole blood cells from active pulmonary TB patients and healthy donors (non-TB) were measured after PHA and MTB specific antigen stimulation time dependently and the results were compared.

The study was approved by the Institutional Ethics Committee of Yonsei University Severance Hospital (approval number 4-2010-0527) and Yonsei University Wonju Campus (approval number 2012-3) and all participants provided written informed consent. MTB culturing confirmed individuals from respiratory specimens were considered as active pulmonary TB group. Individuals with HIV infection, end-stage renal disease, or leukemia/ lymphoma, and those who had received anti-TB therapy for more than 2 weeks or immunosuppressive therapy, including anti-cancer chemotherapy for malignant disease, within 3 months of enrollment, were excluded from the study. Enrolled healthy (non-TB) control group contains young healthy adults (20s) with no symptoms of active TB, no known history of contact with $\mathrm{TB}$ patients. T-cell mitogen stimulation was performed using the commercial mitogen tubes, QFT-IT test Mitogen tube (Cellestis, Carnegie, Australia) which contains anticoagulant and PHA. One mL of peripheral whole blood samples were collected into mitogen tubes and incubated at $37^{\circ} \mathrm{C}$ for $30 \mathrm{~min}, 1,2,4,6$, 8,10 , and $24 \mathrm{~h}$. Plasma was removed by centrifugation at $2,000 \mathrm{x} g$ for $5 \mathrm{~min}$, mitogen stimulated whole blood cell pellets were treated with RNA/DNA Stabilization Reagent for Blood/Bone Marrow solution (Roche Diagnostics, Mannheim, Germany) and stored at $-80^{\circ} \mathrm{C}$ until for total RNA isolation. MTB-specific antigen stimulation was performed using the commercial antigen tubes, QFT-IT test MTB specific antigen tube (Cellestis, Carnegie, Australia) which contains anticoagulant and ESAT-6, CFP-10 and TB7.7. One $\mathrm{mL}$ of peripheral whole blood samples were collected into antigen tubes and incubated at $37^{\circ} \mathrm{C}$ for 30 min, 2, 4, and $24 \mathrm{~h}$. Plasma was removed by centrifugation at 2,000 $\mathrm{x}$ g for $5 \mathrm{~min}$, mitogen stimulated whole blood cell pellets were treated with RNA/DNA Stabilization Reagent for Blood/Bone Marrow solution (Roche Diagnostics, Mannheim, Germany) and stored at $-80^{\circ} \mathrm{C}$ until for total RNA isolation. MagNA Pure LC 2.0 instrument and MagNA Pure LC RNA Isolation Kit-High Performance (Roche Diagnostics, Mannheim, Germany) were was used for isolating total RNA from T-cell mitogen and MTB specific antigen stimulated whole blood cells. Complementary DNA (cDNA) was synthesized by M-MLV Reverse Transcriptase kit and random hexamers (Invitrogen, Carlsbad, CA, USA) with manufacturer's recommendations. Briefly, $10 \mu \mathrm{L}$ of extracted total RNA was added to master mixture containing $1 \mu \mathrm{L}$ of $10 \mathrm{mM} \mathrm{dNTP}$ mix, $0.25 \mu \mathrm{g}$ of random hexamers, and $5 \mu \mathrm{L}$ of DEPC-treated water in PCR tubes, and the reaction mixture was incubated at $65^{\circ} \mathrm{C}$ for $5 \mathrm{~min}$ and quickly chilled on ice. Subsequently the mixture of $4 \mu \mathrm{L}$ of $5 \times$ First-Strand Buffer, $2 \mu \mathrm{L}$ of $0.1 \mathrm{M}$ dithiothreitol (DTT), and $1 \mu \mathrm{L}$ of (M-MLV) reverse transcriptase (RT) was added 
to the previous reaction mixture in PCR tubes and the second reaction was performed at the condition of $10 \mathrm{~min}$ at $25^{\circ} \mathrm{C}, 50 \mathrm{~min}$ at $37^{\circ} \mathrm{C}$, and $15 \mathrm{~min}$ at $70^{\circ} \mathrm{C}$. Real-time RT-PCR was performed using the TaqMan assay with ABI 7500 FAST instrument (Applied Biosystems, Foster City, CA, USA). Targets for real-time RT-PCR were IFN- $\gamma$, TNF- $\alpha$, IL-2R, IL-4, IL-10, CXCL9, CXCL10, CXCL11, and glyceraldehyde 3-phosphate dehydrogenase (GAPDH). The real-time PCR premix contained $10 \mu \mathrm{L}$ of PreMix $E X$ Taq (TaKaRa Bio Inc., Shiga, Japan), 10 pmol sense and antisense primers, 5 pmol TaqMan probes, and $3 \mu \mathrm{L}$ of cDNA in a final volume $20 \mu \mathrm{L}$. The thermal cycling conditions were $10 \mathrm{~min}$ at $95^{\circ} \mathrm{C}$, followed by 40 cycles of $10 \mathrm{~s}$ at $95^{\circ} \mathrm{C}, 30 \mathrm{~s}$ at $60^{\circ} \mathrm{C}$. The standard curves for the target and references genes indicated the efficacy of the method $(>$ $90 \%$ ). The relative quantitation was automatically analyzed using 7500 Software version 2.0.4 (Applied Biosystems, Foster City, CA, USA) with Quantitation-Comparative threshold cycle $(\mathrm{Ct})$ protocol which was based on the 2-DDCT method; relative expression was calculated as the ratio between the mean $\mathrm{Ct}$ values of the target genes and endogenous reference gene in each stimulated sample in relation to a unstimulated sample (Kim, 2013).

To determine the initiation time point of mRNA expression levels of TH1-type factors (IFN- $\gamma$, TNF- $\alpha$, and IL-2R), TH2-type cytokines (IL-4 and IL-10), and IFN- $\gamma$-induced chemokines (CXCL9, CXCL10, and CXCL11) after T-cell mitogen stimulation, peripheral whole blood were stimulated with PHA and blood cell pellets were harvested at $30 \mathrm{~min}$ and $1,2,4,6,8,10$, and $24 \mathrm{~h}$ after incubation. In the TH1-type factor group, IFN- $\gamma$ mRNA expression was detected at $30 \mathrm{~min}$, it increased up to $2 \mathrm{~h}$, and then it decreased until $24 \mathrm{~h}$ in a time-dependent manner. The TNF- $\alpha$ mRNA expression level was the highest in the early time points ( $30 \mathrm{~min}$ and $1 \mathrm{~h}$ ), remained constant up to $2 \mathrm{~h}$ and then significantly reduced from $4 \sim 24 \mathrm{~h}$. The IL-2R mRNA expression level increased from $30 \mathrm{~min}$ to $8 \mathrm{~h}$ time dependently and was constant between 8 and 24 h (Fig. 1-A). In summary, in samples treated with the T-cell mitogen (PHA), the IFN- $\gamma$ mRNA expression level peaked at $2 \mathrm{~h}$, the TNF- $\alpha$ mRNA expression level was significantly high in the early time points, and the IL-2R mRNA expression

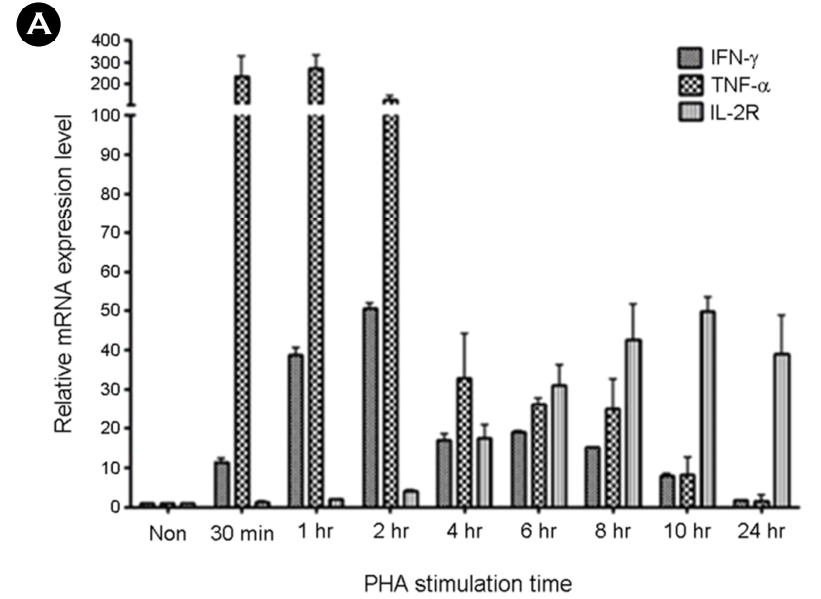

B

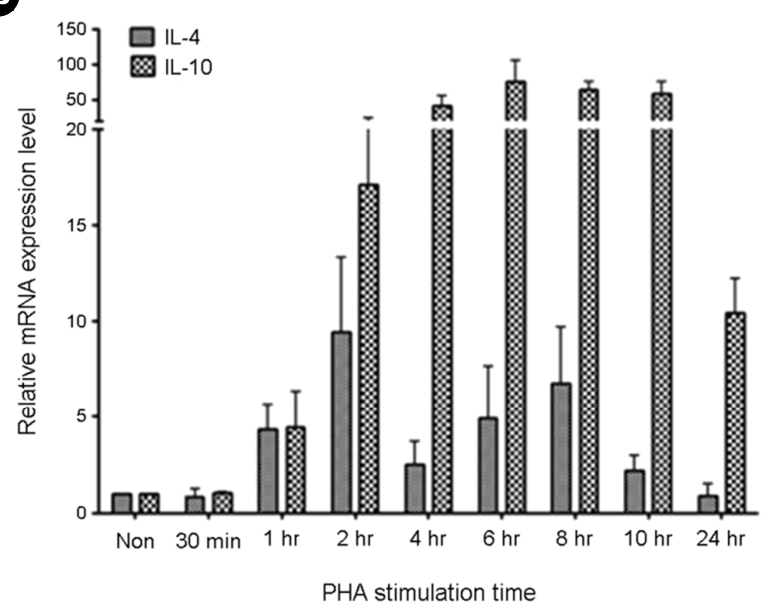

C

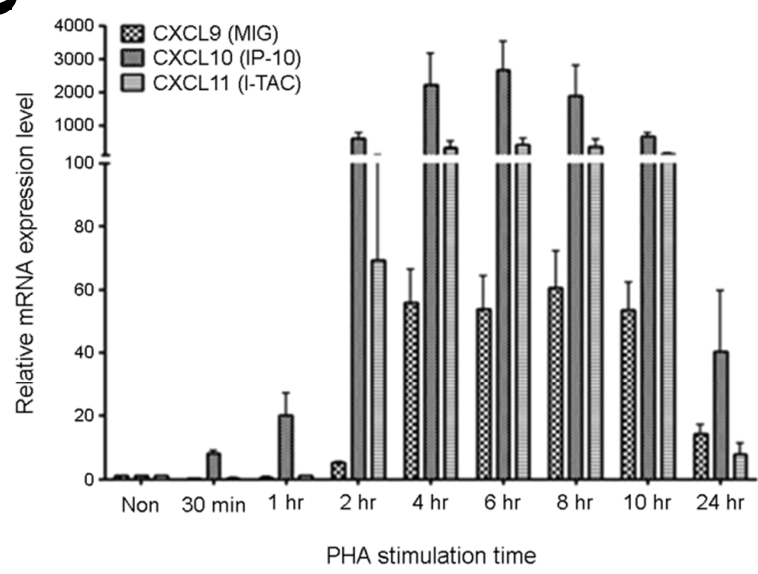

Fig. 1. The changes of target gene mRNA expression level after stimulation of T-cell mitogen in time dependent manner. Whole blood was stimulated with T-cell mitogen (PHA) for indicated time period $(0,30 \mathrm{~min}, 1,2,4,6,8,10$, and $24 \mathrm{~h})$. The target gene (A. TH1-type factors; IFN- $\gamma$, TNF- $\alpha$ and IL-2R, B. TH2-type cytokines; IL-4 and IL-10, C. IFN- $\gamma$ induced chemokines; CXCL9 (MIG), CXCL10 (IP-10) and CXCL11 (I-TAC)) mRNA expression levels of whole blood cells were analyzed by real-time RT-PCR. 
level increased in the late time points (after $8 \mathrm{~h}$ ) in a time-dependent manner. All these changes occurred after activation of other TH1-type cytokines (IFN- $\gamma$ and TNF- $\alpha$ ). In the TH2-type cytokine group, IL-4 mRNA expression was detected at $1 \mathrm{~h}$, increased up to $2 \mathrm{~h}$, decreased at $4 \mathrm{~h}$, increased again at $6 \sim 8 \mathrm{~h}$ and decreased until $24 \mathrm{~h}$ time dependently. IL-10 mRNA expression was detected at $1 \mathrm{~h}$, increased until $4 \mathrm{~h}$, was constant between 4 and $10 \mathrm{~h}$ and decreased at $24 \mathrm{~h}$ (Fig. 1-B). In summary, IL-4 mRNA expression peaked at 2 time points. IL-10 mRNA expression remained constant for a longer time $(2 \sim 10 \mathrm{~h})$ than that of other targets genes. In the IFN- $\gamma$-induced chemokine group, CXCL9 and CXCL11 mRNA expression increased at $2 \mathrm{~h}$, was constant between 4 and $10 \mathrm{~h}$ and decreased at $24 \mathrm{~h}$. The CXCL10 mRNA expression increased from $30 \mathrm{~min}$ to $2 \mathrm{~h}$, was constant between 2 and $10 \mathrm{~h}$, and decreased at 24 h (Fig. 1-C). In summary, the mRNA expression of the three IFN- $\gamma$-induced chemokine (CXCL9, CXCL10, and CXCL11) remained constant for a longer time (2 10 h) with a significantly higher expression level than those of other groups (TH-1 type factors and TH-2 type cytokines) when stimulated with PHA. To determine the changes of mRNA expression levels of eight target genes (IFN- $\gamma$, TNF- $\alpha$, IL-2R, IL-4, IL-10, CXCL9, CXCL10, and CXCL11) after MTB specific antigen stimulation, peripheral blood was collected from active TB patients and healthy controls in two QFT-IT tubes (MTB specific antigen; ESAT-6, CFP-10, TB7.7 and nil). Blood cell pellets were harvested at $30 \mathrm{~min}$ and 2, 4, and $24 \mathrm{~h}$ after incubation for total RNA isolation. Plasma samples were also collected at the same points to measure the plasma target protein levels. Target genes were grouped as. In the TH1-type factor group in active TB patients' samples, IFN- $\gamma$ mRNA expression was detected at $30 \mathrm{~min}$, increased up to $4 \mathrm{~h}$, and decreased until $24 \mathrm{~h}$ in a time-dependent manner. TNF- $\alpha$ and IL-2R mRNA expression was constant until $4 \mathrm{~h}$ and peaked at $24 \mathrm{~h}$ (Fig. 2-A). However, the mRNA expression of IFN- $\gamma$, TNF- $\alpha$, and IL-2R did not respond to MTB specific antigens in healthy controls samples (Fig. 3-A). In active TB patients' samples treated with MTB specific antigens, IFN- $\gamma$ mRNA expression peaked at $4 \mathrm{~h}$, and TNF- $\alpha$ and IL-2R mRNA expression was significantly high at the late time points $(24 \mathrm{~h})$.

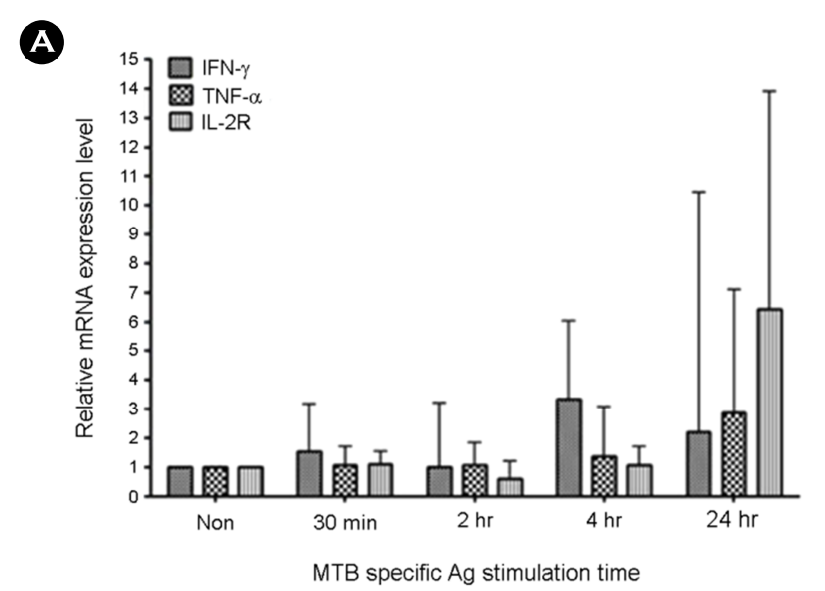

B

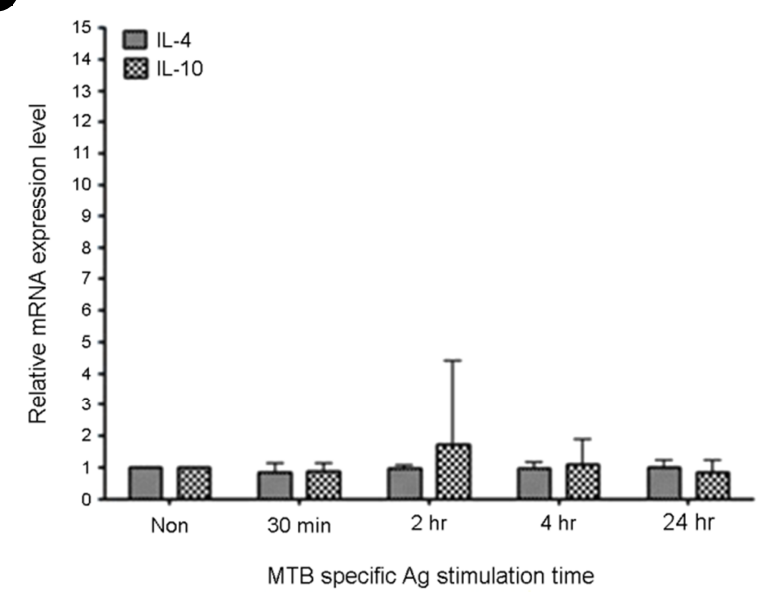

C

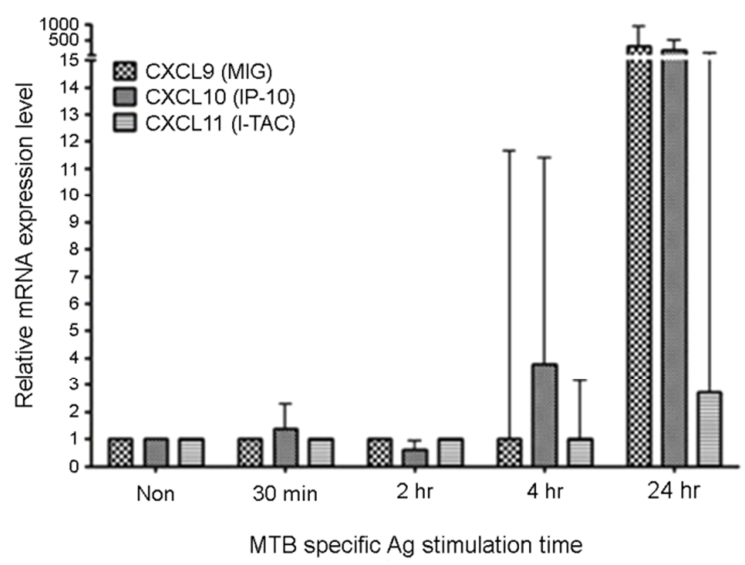

Fig. 2. The changes of target gene mRNA expression level after stimulation of MTB specific Antigen in time dependent manner in samples from active TB patients. Whole blood from active TB patients was stimulated with MTB specific antigens (ESAT-6, CFP-10 and TB7.7) for indicated time period (0,30 min, 2, 4 and $24 \mathrm{~h}$ ). The target gene (A. TH1-type factors; IFN- $\gamma$, TNF- $\alpha$ and IL-2R, B. TH2-type cytokines; IL-4 and IL-10, and C. IFN- $\gamma$ induced chemokines; CXCL9 (MIG), CXCL10 (IP-10) and CXCL11 (I-TAC)) mRNA expression levels of whole blood cells were analyzed by real-time RT-PCR. 


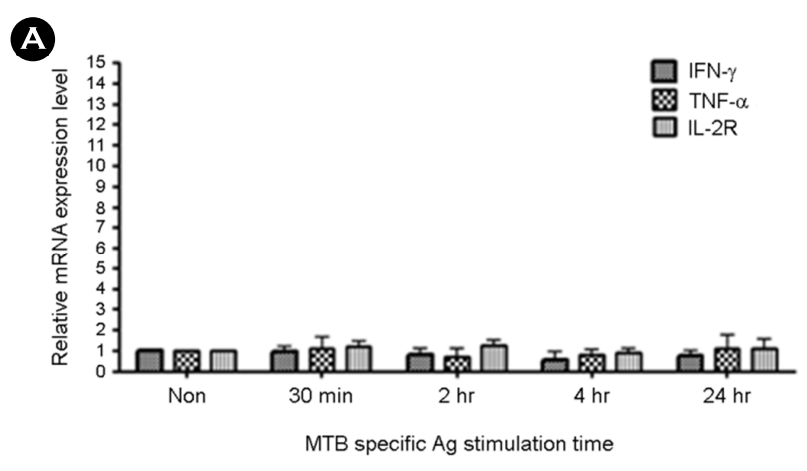

B

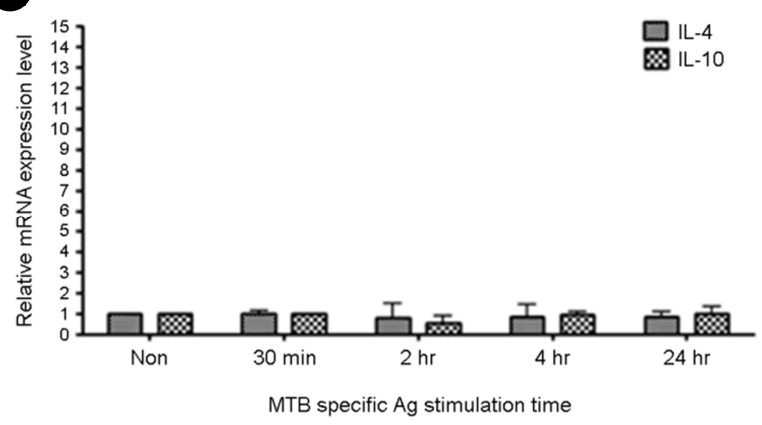

C

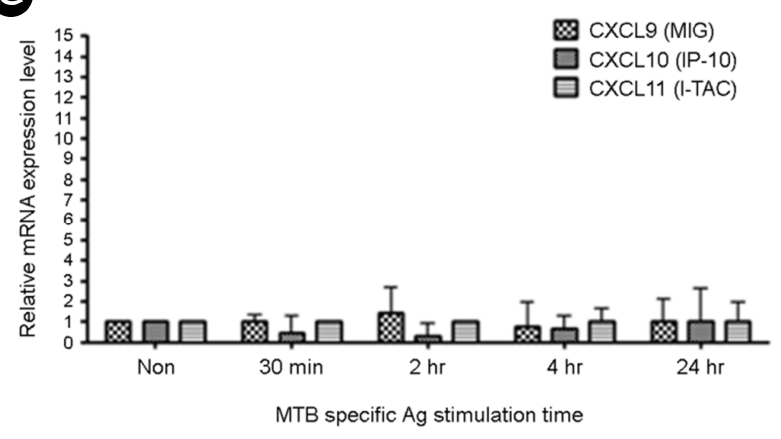

Fig. 3. The changes of target gene mRNA expression level after stimulation of MTB specific antigens in time dependent manner in samples from healthy controls. Whole blood from healthy controls was stimulated with MTB specific antigens (ESAT-6, CFP-10 and TB7.7) for indicated time period $(0,30 \mathrm{~min}, 2,4$ and $24 \mathrm{~h}$ ). The target gene (TH1-type factors; IFN- $\gamma$, TNF- $\alpha$ and IL-2R, TH2-type cytokines; IL-4 and IL-10, and IFN- $\gamma$ induced chemokines; CXCL9 (MIG), CXCL10 (IP-10) and CXCL11 (I-TAC)) mRNA expression levels of whole blood cells were analyzed by real-time RT-PCR.

In the TH2-type cytokine group in active TB patients' samples, IL-4 and IL-10 mRNA expression was constant from the early time point to the late time point (Fig. 2-B). It did not respond to MTB specific antigens in healthy controls samples (Fig. 3-B). These data reveal that TH2-type cyto- kine mRNA expression levels in both active TB and healthy controls samples did not change significantly after MTB specific antigen stimulation. In the IFN- $\gamma$-induced chemokine group, CXCL9 mRNA expression was constant until $4 \mathrm{~h}$ and increased significantly at $24 \mathrm{~h}$. CXCL10 mRNA expression increased at $4 \mathrm{~h}$ and was significantly high at 24 h. CXCL11 mRNA expression was constant until $4 \mathrm{~h}$ and increased slightly at $24 \mathrm{~h}$ (Fig. 2-C). However, the mRNA expression of CXCL9, CXCL10, and CXCL11 did not respond to MTB specific antigens in healthy control samples (Fig. 3-C). In summary, the mRNA expression of the three IFN- $\gamma$-induced chemokines (CXCL9, CXCL10, and CXCL11) peaked at the late time points $(24 \mathrm{~h})$. In particular, CXCL9 and CXCL10 mRNA expression at $24 \mathrm{~h}$ was several hundred times higher than those of other targets in response to MTB specific antigens. CXCL10 mRNA was expressed earlier than CXCL9 and CXCL11 mRNA. In conclusion, the mRNA expression patterns of the TB-related immune markers in response to the T-cell mitogen (PHA) differed from those in response to MTB specific antigens. Because the concentration of the peptide antigen was much higher in the T-cell mitogen control than in the MTBspecific antigen control, overall target mRNA expression was initiated at an early time point in the T-cell mitogen control. Additionally, while PHA first causes mitosis specifically in T-cells among the immune cells, MTB specific antigens simultaneously stimulate various immune cells in whole blood cells. There were no significant changes of cytokine and chemokine mRNA expression by MTB specific antigens stimulation in healthy controls comparing to the active TB patients because the healthy controls involved in the present study did not have active TB symptoms and signs, and did not have any previous TB history. These results may contribute to a better understanding of the relationship between MTB specific antigens and host immune markers in a transcript level. In addition, these also provide essential information for development of next generation TB immunodiagnostic testing.

\section{Acknowledgements}

This study was supported by a grant of the Korea Healthcare technology R\&D Project, Ministry of Health \& 
Welfare, Republic of Korea (grant HI10C1708 [A101750] to H. L.). This work was supported (in part) by the Yonsei University Research Fund of 2013.

\section{REFERENCES}

Adane M, Markos A. Cytokines and Chemokines as Biomarkers of Tuberculosis. J Mycobac Dis. 2013. 3: 1-4.

Azzurri A, Sow OY, Amedei A, Bah B, Diallo S. IFN-gamma inducible protein 10 and pentraxin 3 plasma levels are tools for monitoring inflammation and disease activity in $\mathrm{Myco}-$ bacterium tuberculosis infection. Microbes Infect. 2005. 7: $1-8$.

Behr MA, Wilson MA, Gill WP, Salamon H, Schoolnik GK, Rane S, Small PM. Comparative genomics of BCG vaccines by whole genome DNA microarray. Science. 1999. 284: 1520 -1523 .

Brosch R, Gordon SV, Marmiesse M, Brodin P, Buchrieser C, Eiglmeier K, Garnier T, Gutierrez C, Hewinson G, Kremer K, Parsons LM, Pym AS, Samper S, Soolingen D van, Cole ST. A new evolutionary scenario for the Mycobacterium tuberculosis complex. Proc Natl Acad Sci USA. 2002. 99: 3684-3689.

Cole ST, Brosch R, Parkhill J, Garnier T, Churcher C, Harris D, Gordon VS, Eiglmeier K, Gas S, Barry III CE, Tekaia F, Badcock K, Basham D, Brown D, Chillingworth T, Connor R, Davies R, Devlin K, Feltwell T, Gentles S, Hamlin N, Holroyd S, Hornsby T, Jagels K. Deciphering the biology of Mycobacterium tuberculosis from the complete genome sequence. Nature. 1998. 393: 537-544.

Comstock GW, Livesay VT, Woolpert SF. The prognosis of a positive tuberculin reaction in childhood and adolescence. Am J Epidemiol. 1974. 99: 131-138.

Dlugovitzky D, Bay ML, Rateni L, Urizar L, Rondelli CF. In vitro synthesis of interferon-gamma, interleukin-4, transforming growth factor-beta and interleukin-1 beta by peripheral blood mononuclear cells from tuberculosis patients: relationship with the severity of pulmonary involvement. Scand J Immunol. 1999. 49: 210-217.

Dye CS, Schelle P, Dolin V, Pathania, Raviglione MC. Global burden of tuberculosis: estimated incidence, prevalence, and mortality by country. JAMA. 1999. 282: 677-686.

Golden MP, Vikram HR. Extrapulmonary tuberculosis: an overview. Am Fam Physician. 2005. 72: 1761-1768.

Hamelryck TW, Dao-Thi MH, Poortmans F, Chrispeels MJ, Wyns L, Loris R. The crystallographic structure of phytohemagglutinin
-L. J of Biol Chem. 1996. 271: 20479-20485.

Harari A, Rozot V, Enders FB, Perreau M, Stalder JM. Dominant TNF-alpha+ Mycobacterium tuberculosis-specific CD4+ T cell responses discriminate between latent infection and active disease. Nat Med. 2011. 17: 372-376.

Juffermans NP, Verbon A, van Deventer SJ. Elevated chemokine concentrations in sera of human immunodeficiency virus (HIV)-seropositive and HIV-seronegative patients with tuberculosis: a possible role for mycobacterial lipoarabinomannan. Infect Immun. 1999. 67: 4295-4297.

Kaplan G, Luster AD, Hancock G, Cohn ZA. The expression of a gamma interferon-induced protein (IP-10) in delayed immune responses in human skin. J Exp Med. 1987. 166: 1098-1108.

Kim S, Kim YK, Lee H, Cho J-E, Kim HY, Uh Y, Kim YM, Kim $\mathrm{H}$, Cho S-N, Jeon B-Y, Lee H. Interferon gamma mRNA quantitative real-time polymerase chain reaction for the diagnosis of latent tuberculosis: a novel interferon gamma release assay. Diagn Microbiol and Infect Dis. 2013. 75: 68-72.

Lew WT, Lee EG, Kwon DW, Kim SJ, Hong YP, Kim JB. The fate of intractable tuberculosis cases under national tuberculosis programme. Tuberc and Resp Dis. 1995. 42: 11-18.

Meher AK, Bal NC, Chary KV, Arora A. Mycobacterium tuberculosis H37Rv ESAT-6-CFP-10 compleand biochemical stability". FEBS J. 2006. 273: 1445-1462.

Okamoto M, Kawabe T, Iwasaki Y. Evaluation of interferongamma, interferon-gamma-inducing cytokines, and interferongamma-inducible chemokines in tuberculous pleural effusions J Lab Clin Med. 2005. 145: 88-93.

Pathak SK, Basu S, Basu KK, Banerjee A, Pathak S, Bhattacharyya A, Kaisho T, Kundu M, Basu J. Direct extracellular interaction between the early secreted antigen ESAT-6 of Mycobacterium tuberculosis and TLR2 inhibits TLR signaling in macrophages. Nat Immunol. 2007. 8: 610-618.

Renshaw PS, Lightbody KL, Veverka V, Muskett FW, Kelly G, Frenkiel TA, Gordon SV, Hewinson RG, Burke B, Norman J, Williamson RA, Carr MD. Structure and function of the complex formed by the tuberculosis virulence factors CFP-10 and ESAT-6. EMBO J. 2005. 24: 2491-2498.

Ulrichs T, Munk ME, Mollenkopf H, Behr-Perst S, Colangeli R. Differential T cell responses to Mycobacterium tuberculosis ESAT6 in tuberculosis patients and healthy controls. Eur J Immunol. 1998. 28: 3949-3958

Walzl G, Ronacher K, Hanekom W, Scriba TJ, Zumla A. Immunological biomarkers of tuberculosis. Nat Rev Immunol. 2011 11: 343-354 